\title{
The Implications of Mandatory Corporate Social Responsibility-A Literature Review Perspective
}

\author{
Dinesh Ramdhony ${ }^{1,2}$ \\ ${ }^{1}$ University of Mauritius, Reduit, Mauritius \\ ${ }^{2}$ University of Southern Queensland, Toowoomba, Australia \\ Email: d.ramdhony@uom.ac.mu
}

How to cite this paper: Ramdhony, D. (2018) The Implications of Mandatory Corporate Social Responsibility-A Literature Review Perspective. Theoretical Economics Letters, 8, 432-447. https://doi.org/10.4236/tel.2018.83031

Received: August 6, 2017

Accepted: February 10, 2018

Published: February 13, 2018

Copyright $\odot 2018$ by author and Scientific Research Publishing Inc. This work is licensed under the Creative Commons Attribution International License (CC BY 4.0).

http://creativecommons.org/licenses/by/4.0/

\section{cc) (i) Open Access}

\begin{abstract}
The purpose of this paper is to discuss the implications of mandatory corporate social responsibility (CSR) contributions: the CSR levy. Using public interest theory as the theoretical lens, this paper adopts a pro-regulation approach and justifies the introduction of the CSR levy in Mauritius, based on the economic and business environment prevailing at the time. Secondary literature sources are used to investigate. Two further questions related to mandatory CSR are investigated: Does the CSR levy result in a competitive disadvantage? Does the CSR levy reduce profits? We conclude that the CSR levy does not disadvantage firms due to the uniform amount and its universal application. Furthermore, it can attract Foreign Direct Investment (FDI) and Socially Responsible Investment (SRI). However, the CSR levy does negatively impact on profits but has the potential to pay higher returns in the future if viewed as an investment. This research needs to be complemented by studies that empirically investigate the impacts of the CSR levy on companies and sectors in Mauritius.
\end{abstract}

\section{Keywords}

Mauritius, Mandatory, CSR Levy, Public Interest Theory

\section{Introduction}

The idea of corporate social responsibility (CSR) dates back to the $20^{\text {th }}$ century (Kristoffersen, Gerrans and Clark-Murphy [1]) and companies have been disclosing information about various aspects of their social and environmental performance for over a century (Deegan [2]). CSR includes those actions which 
go beyond legal requirements and which minimize harm on the firm and society (Bloom and Gundlach [3]). The practice of CSR has turned into a norm rather than exception. This is largely due to the proliferation of multinational companies which export their "western standards" to host countries. Firms are expected to increase shareholders' wealth taking into account the expectations of society. However, lack of engagement of companies with the community and the lack of transparency about the impact of their activities on the society have triggered the idea of mandatory CSR. Though the idea seems contradictory, in the last decade, many countries have taken initiatives to move from voluntary CSR to mandatory CSR. For example, France, Denmark, Norway and South Africa have passed legislation which requires firms to disclose their environmental performance (Ioannou and Serafeim [4]). While the debate was initially centred on CSR reporting, three countries (e.g. Mauritius, India and Indonesia) have gone further and imposed a mandatory CSR contribution by firms (CSR levy). This decision attracted much criticism especially in Indonesia where the legality of mandatory CSR was challenged before the Constitutional Court (Waagstein [5]).

In light of the above discussion, the following research questions arise: 1) Should CSR be mandatory? 2) Does mandatory CSR bring competitive disadvantage? 3) Does mandatory CSR decrease profits? This study aims to shed light on these questions by considering Mauritius as a case study. The decision to focus on Mauritius is motivated by two reasons. First, Mauritius is a pioneer in introducing a CSR levy on all companies irrespective of size and industry. This is in stark contrast with India and Indonesia which apply mandatory CSR selectively. Second, the historical background and social environment of the country are unique. A proper appreciation of the local political and social forces at play are important to understand the pro-regulation approach to CSR in the case of Mauritius.

\section{Background to CSR Legislation in Mauritius}

Mauritius is a former British and French colony. Even more than three decades after independence descendants of European settlers still control private business ownership and hold the bulk of economic power (Maisenhender [6]). An inequality in income and wealth distribution is visible in Mauritius (Mahadeo et al. [7]). CSR activities of Mauritian firms can be traced back to the days where sugar production used to be the main economic activity. Sugar estates and factories were the main employer in the country and used to provide support to activities in their "factory-area". These support activities ranged from helping schools to religious donations. These were made on an ad-hoc basis and could be termed as philanthropic CSR (Soobaroyen and Mahadeo [8]). A survey by the MEF in 2007 found that the majority of businesses are of the view that pursuing their narrow economic interests should be balanced with social and environmental responsibilities. The survey also found that firms were involved in CSR 
activities on an ad-hoc basis which were not linked to their business operations. While $75 \%$ of enterprises claimed that they had a clear CSR policy, only $28 \%$ had a regular budget allocated for CSR. A report by the Joint Economic Council in 2007 report pointed out the lack of coordination and systematic approach of local firms while engaging in CSR activities, which was mainly due to the ad-hoc response (Pineda Escobar [9]).

In its 2007 budget the government made an appeal by requesting (all) companies to contribute more towards CSR activities.

"Most companies, though sensitive to the issue of Corporate Social Responsibility (CSR) do not have structured programmes of support. With the exception of a few companies, CSR is being carried out on an "ad hoc" basis ... it is our conviction that there should be a concrete show of solidarity with the weak, the vulnerable and the poor. To this end, a number of firms in the corporate sector have agreed to voluntarily contribute at least 1 percent of their profits to CSR activities run by them. I make an appeal to companies that can afford it to contribute more." (Ministry of Finance [10])

It seems that the response from the private sector was below expectations. In 2009 the government mandated CSR through “The Finance Bill 2009”. It requires all profitable companies to contribute $2 \%$ of their preceding year profits towards CSR activities. Guidelines for spending CSR funds were formulated by government and employer representatives and aimed at synchronizing CSR activities for the benefit of society and more particularly, the needy.

\section{Theoretical Framework}

Public interest theory holds that regulation is necessary because of market failure. The aim of regulation is to protect the public interest and society who will be better off with regulation than otherwise (Godfrey et al. [11]). Public interest theory assumes that the regulator (government) has an independent role to play in the development of regulation. It rather acts as a neutral arbiter intervening at the request of "public interest" agents. The government does not let its selfinterest prevail in the regulation process (Deegan [12]). Government intervenes to create a regulated financial reporting environment to ensure that firms provide accurate accounting information to the market. Consequently, this improves investor confidence and improves overall market efficiency (Omran and El-Galfy [13]). Omran and El-Galfy [13] argue that public interest theory ignores the opportunistic roles of the regulator, capture of the regulatory process by companies and the private interests of stakeholders. Moreover, the lack of competence of the regulator and their true intention to protect the public interest may compromise the usefulness of this theory (Gaffikin [14]).

\section{Should CSR Be Mandatory?}

The Mauritian business environment is characterized by family owned and managed firms with concentration of ownership among a small percentage of 
the population. Even listed companies have a high influence of family driven management with the same people having stakes in related businesses. This results in a "high level of opacity" in running such enterprises (Soobaroyen and Mahadeo [15]). The smallness of the island and the "tight knit" nature of the business community often results in instances of conflict of interest arising from family/personal relationships among directors/managers and suppliers (NCCG, 2004). Cross shareholding and cross directorship is a common feature among firms in Mauritius. Many successful firms are not listed on the stock exchange as major shareholders do not want to relinquish control (Manos and Ah-hen [16]).

Due to the absence of strong stakeholders, closely held firms face limited pressure to be involved in CSR activities. On the other hand, when shares are widely held with many shareholders owning a small proportion of shares of a company, public accountability becomes an issue. This may necessitate investment in CSR activities (Mohd Ghazali [17]). Ntim and Soobaroyen [18] report a negative relationship between close ownership and CSR disclosures. Al-Bassam et al. [19] found a negative link between close ownership and corporate governance disclosures. There are no prior studies which report empirically the degree of ownership concentration in Mauritius, but the National Code of Corporate Governance [20] acknowledges:

"The shareholding of the corporate sector in Mauritius is concentrated in a small percentage of the population. Such concentration exists in many other economies and may not be negative for economic growth, but a wider ownership is desirable in Mauritius. Such a change would provide the corporate sector with greater support from the Mauritian society as a whole, and allow more people from all communities to be shareholders in the economy".

The existence of a dominant group of individuals which is able to influence board decisions, is common in family owned business. This is because the controlling shareholder will be able to nominate friends/relatives to the board (Lokman, Mula and Cotter [21]). Family members compared to other investors are less concerned about accountability and organizational legitimacy (Khan, Muttakin and Siddiqui, [22]). As such family controlled businesses are less likely to embrace social goals. Moreover, the cost of engaging in CSR might outweigh the benefits. Chau and Gray [23], Haniffa and Cooke [24], Ho and Wong [25] and Gazali and Weetman [26] found a negative relationship between family controlled businesses and voluntary disclosure.

The Mauritian government has shareholdings in several companies. Areas of strategic importance mainly determine government ownership. Some state enterprises such as the Central Electricity Board and the Central Water Authority are run as parastatal bodies. Other companies are run as public limited companies and have the government and other governmental agencies as well as the private sector as shareholders (NCCG [20]). Since, the activities of these public companies are under public scrutiny, they are expected to be more involved in CSR (Mohd Ghazali [17]). Public companies have directors nominated by the government who have the responsibility to execute the government's mission. 
However, the Mauritian government has a significant shareholding in only a couple of listed companies.

In comparison, 57 government linked companies are listed on Bursa Malaysia (Najid and Rahman [27]). Amran and Devi [5] and Haji and Ghazali [28] found a significant positive relationship between government shareholding and CSR disclosure. The Mauritian government is unable to propagate its CSR philosophy on companies through a presence on the board of directors. Further, a number of government enterprises have been making continuous losses and consequently have not allocated funds for CSR. The government through its enterprises has not been a "CSR champion".

Public interest theory posits that regulation becomes desirable because of market failure. The actual ownership structure of firms which is concentrated among few individuals offers no incentive for firms to spend on CSR as they are faced with less powerful stakeholders. Family run firms having concentrated ownership tend to treat CSR as a trivial matter. In these conditions, compulsion is the only way to ensure genuine CSR actions.

CSR guidelines, which prescribe that half of CSR funds are to be allocated to priority areas, ensure that resources are put to effective use. Without regulation it will be difficult to channel resources towards areas which require intervention. Prior to the CSR levy, the voluntary nature combined with the concentrated ownership structure encouraged firms to practice internal CSR activities. Training was preferred CSR activity of firms (MEF [29]). The community was therefore only a minor beneficiary of CSR activities. Furthermore, "Donations" was the most popular form of external CSR activity (MEF [29]). While charitable donations are presumed to benefit the community at large, religious donations benefit only a section of the community. An overhaul of the CSR landscape was therefore necessary to synchronize CSR activities and prioritize certain areas. The CSR levy aimed to achieve these objectives.

Mandatory CSR supports the role of the government in protecting the environment and raising the standard of living of people (Japhet et al. [30]). The government on its own is unable to meet the expectations of the society. Allowing firms to manage CSR projects from their CSR funds allows firms to innovate in meeting society's needs. With several parties involved, the needs of the society are met faster compared to a centralised body keeping custody of funds centrally. Based on the findings of MEF [31] whereby only a minority of companies were found to allocate funds to CSR, it can be argued that the CSR levy will enable firms to respond spontaneously if the need arises, for example in the case of a catastrophe. The CSR levy with guidelines for spending is the best mix between the two extremes of keeping full custody and control over CSR funds by the government and leaving all CSR funds with all control in the hands of companies. The actual situation is therefore ideal for both companies and the government.

\section{Does the CSR Levy Result in Competitive Disadvantage?}

Those who oppose mandatory CSR, claim that the CSR levy is equivalent to a 
tax. The tax will negatively impact on the country's ability to attract Foreign Direct Investment (FDI). LDCs rely on FDI to acquire technology and knowledge (Blin and Ouattara [32]) and is one of the main conductors of economic growth (Seetanah [33], Li and Liu [34]). Various road shows have been organized in a bid to lure European and other investors to Mauritius. Wahid and Seetanah [35] found that the main determinants of FDI in Mauritius are the trade openness of the country and the low wage rate and high quality of the labour force. They claimed that the low tax rate in Mauritius is of negligible value in attracting investment. Moreover, Mauritius is a low tax regime, corporation tax is a uniform $15 \%$ and compares favourably with other African countries. For instance, South Africa, Botswana and Zimbabwe have all a corporate tax rate in excess of $25 \%$. A poor reputation on CSR will affect the ease with which the Mauritian government can attract investors. Arthur Levitt, the former Chairperson of the US Securities and Exchange stated:

"If a country does not have a reputation for strong corporate governance practices, capital will flow elsewhere. If investors are not confident with the level of disclosure, capital will flow elsewhere. If a country opts for lax accounting and reporting standards, capital will flow elsewhere. All enterprises in that country-regardless of how steadfast a particular company's practices may be-suffer the consequences".

The levy enhances the country's reputation by sending a strong signal to investors that Mauritius values CSR. Developing countries normally have a poor reputation for CSR. Media reports of the existence of sweatshops in Asian countries have affected the reputation of several multinationals (Islam and Deegan, 2008). The CSR levy therefore reassures investors that Mauritian companies follow sound CSR practices.

The country's improved reputation due to the CSR levy can affect Mauritian companies in several ways. It can improve the ease with which Mauritian companies can enter and operate in countries which attach importance to CSR, for example, Norway (Turner [36]). Mandatory CSR can boost the country's exports to developed countries. Buyers from developed countries are increasingly cautious when trading with developing countries in the wake of allegations of unethical practices such as the use of child labour. Mandatory CSR reassures foreign buyers that Mauritian products have been produced under ethical conditions.

Socially Responsible Investment (SRI) is gaining prominence among investors. For instance more than $10 \%$ of assets under management in the USA follow the SRI criteria (Cormier et al. [37]). Major stock exchanges now have a sustainability index. Mandatory CSR can increase the buoyancy on the Stock Exchange of Mauritius (SEM) by attracting socially responsible investors. Probably the biggest advantage of mandatory CSR can be the ability to attract global funds which use SRI guidelines. The responsible investment community manages around $\$ 3$ trillion of assets in the United States alone (O’Rourke [38]). Several 
firms from Malaysia, Sri Lanka, Morocco and Thailand have been rejected outright by the California Public Employees Retirement System (CalPERS), which is the world's largest pension fund, because they do not meet the SRI criteria of CalPERS (Dhooge [39]). Mandatory CSR gives the opportunity to attract SRI funds from overseas to invest on the SEM. Mauritius sources $74 \%$ of its FDI from European countries. In these countries, CSR is quasi-mandatory for firms to maintain their "license" to operate. Thus, the CSR levy should encourage European investors to invest in Mauritius.

The second part of the discussion on competitive disadvantage focuses on whether companies contributing to the CSR levy are disadvantaged. There are two ways in which mandatory CSR can lead to competitive disadvantage.

First, is when companies are not equally affected by regulation. Mandatory regulation of CSR in Indonesia and India can explain this point. Indonesian statutory regulation on CSR applies only to companies which extract natural resources. While companies operating in the natural resources sector will be affected equally this will advantage companies operating in other sectors. The matter has been raised in the Constitutional Court which deliberated that the law is not discriminatory. The court stated that mandatory CSR is a preventive effort as the business activities of those firms operating in the sector have negative consequences on the stock of natural resources and the lives of people (Waagstein [5]). CSR regulation in India also applies to "capable" companies which imply that companies falling within this definition will be disadvantaged. Countries such as Australia, the UK and the US have discriminatory laws against large companies often requiring companies over a turnover threshold or number of employees to apply certain rules (Deva [40]). Compared to Indonesia and India, the CSR levy in Mauritius applies to all companies. As the rate of the CSR levy is uniform and its application is related to profit irrespective of the amount, it can be argued that CSR levy in Mauritius will affect all entities equally. Therefore, the levy in no way puts a contributing entity at a competitive disadvantage.

Second, is where competitive advantage is associated exclusively to financial gain. Protection of the environment or empowering the community goes beyond the scope of business. Companies should not view expenditure on protecting the environment or empowering the community as a cost but rather as a long term investment. Empowering the community will make people more employable which increase income and ultimately create demand for the company's product/services. Even if CSR is considered an expense, it has the potential to provide returns in excess of the cost, in the long run (Waagstein [5]).

Porter and Kramer [41] argue that "CSR can be much more than a cost, a constraint, or a charitable deed-it can be a source of opportunity, innovation, and competitive advantage". CSR has been the bone of contention between corporations and society. Of the four valid arguments (moral obligation, sustainability, licence to operate and reputation) to justify CSR, all focus on the tension between the organisation and society instead of recognising the mutual dependence of society and the organisation (Porter and Kramer [41]). The authors ad- 
vise companies to follow the principle of "shared values" for each other's benefit. They argue that the guide to engage in a CSR activity is not whether the cause is worthy but whether it can be beneficial to both society and the business at the same time. In so doing firms can build competitive advantage. For example, Volvo has built competitive advantage around its safety technology which is beneficial to both the company and society. The increasing concern by the community for the environment has forced companies to innovate towards a number of "green" products which benefit both the environment and the business. The introduction of hybrid cars is a good example. McWilliams et al. [42] further argue that CSR can enable a firm to differentiate its product. For example the hybrid version of the Honda Accord generates less pollution than the standard version of the Honda Accord. Some customers are willing to pay extra due to this additional feature. This type of product differentiation allows the firm to meet customer demand and at the same time maintain or enhance its reputation.

CSR is often portrayed as a charitable donation with no benefit to the donor. CSR is therefore seen as being incompatible with profit maximization. However, CSR can also be strategic whereby it can combine economic and social benefits (Husted and Salazar [43]). Jain and Jamali [44] argue that the outside-in approach of strategic philanthropy where the business makes contributions to enhance the outside business environment, reaps benefits in the long run. The business depends on human resources and physical infrastructure to further its activities. When business benefits are linked to society, the outside-in approach sets in a cyclical loop which reconciles economic and social goals through the convergence of economic and social interests. Strategic CSR is a win-win situation from both a financial and ethical perspective. Companies which are attentive to the demands of stakeholders are rewarded by them in the form of favourable consumer behaviour, more customer loyalty and greater revenue (AminChaudhry).

Attracting and retaining human resources is central for the success of an organisation. Companies with high corporate social performance are more appealing to job seekers that those with low CSP (Albinger and Freeman [45]) and companies with good social credentials have better employee retention rates (Peterson [46]). Stites and Michael [47] investigated whether employee perception of CSP influences the affective organisational commitment, found that communicating CSR to employees can improve employee attitudes which in turn can influence turnover and performance. In another study, Carmeli et al. [48] found that employees have stronger identification with high social performance compared to high financial performance.

\section{Will Mandatory CSR Decrease Profits?}

The CSR levy is a cost to the business. The impact on profit will depend on whether the business was involved in CSR prior to introduction of the CSR levy. 
Some firms were already spending some of their profit on CSR prior to the introduction of the CSR levy. For these firms the CSR levy will barely affect their net profit. In addition to the cost of CSR initiatives, businesses have to incur the cost of monitoring and implementing these programs. For this reason, firms were reluctant to participate in CSR programs (Sethi [49]). However, in Mauritius, the guidelines for spending of CSR funds provide for up to $15 \%$ to be spent on administrative expenses. Additionally, firms may incur expenses for complying with standards (e.g. GRI) and have to incur the cost of external auditing and certification (Waagstein [5]). These costs are quite considerable and would be incurred by large companies. As there is no statutory obligation to have CSR reports audited, firms can avoid this cost. Barnea and Rubin [50] contend that insiders (corporate managers, directors and large block holders) tend to over-invest in CSR for their own personal benefit at the expense of shareholders. A favourable CSR rating will improve the reputation of insiders being perceived as caring towards employees and the community. As a result CSR becomes a source of conflict between shareholders because of fear that over-investment in CSR will reduce the firm's value. To this end CSR will impact negatively on profit (Jo and Harjoto [51]).

There are also claims that CSR expenditure can lead to higher profits. Amin-Chaudhry argues that investment in CSR can bring higher profit because stakeholders require firms to behave in a socially responsible manner and such behaviour is rewarded by the market. She cites the example of British retailer Marks and Spencer (M \& S) which adopted a CSR program called Plan A in 2007. This initiative had four categories: climate change, waste, sustainable material and health. In 2012, Marks and Spencer Group reported an increase net profit of $£ 105$ million by adopting Plan A showing the positive effect of CSR on financial performance. Orlitzky et al. [52] conducted a meta-analysis of 52 studies on the relationship between corporate social and financial performance. They report that corporate social performance predicted corporate financial performance but also that corporate financial performance predicted corporate social performance. Firms which spend on CSR can expect enhanced reputations which can increase their customer base to reap higher profits. However, empirical evidence on the relationship between CSR and profit is inconclusive (Mahadeo et al. [48], Purushothaman et al. [53]. A meta-analysis by Griffin and Mahon [54] of the CSP and CFP link found nine cases with no definite result, 33 cases showing a positive correlation and 20 negatively associated. Inconsistency in the results regarding the association between CSP and CFP may be due to the data and the variety of measures used for CSP and CFP (Usman and Amran [55]). If costs are certain and benefits are unsure, the question arises: Should firms still carry out CSR? The CSR levy is a mandatory obligation similar to taxation and businesses must comply with law. Mandatory CSR can be viewed as a tax imposed by society for using its services. Society provides the human, environment and other resources to businesses to further their activities. 
The common argument that CSR will increase cost is based on a restricted definition of cost which is based on general accepted accounting practices. A business creates externalities which can either be positive (benefit) or negative (cost). Traditional accounting does not account for these externalities. Consequently, the cost of a product/service is understated which encourages higher production and consumption than which would be otherwise, if the cost to the society is considered. For example, a manufacturing firm creates pollution from its production activities. If the air which it pollutes is considered a "free good" then obviously, higher production will lead to higher profit (Deegan [2]). Conversely, if an organisation adopts a "full cost" approach whereby it accounts for the cost incurred to ameliorate the pollution, then the question of CSR leading to lower profit may not arise as the financial performance of so called "good companies" may show a very different result. "Full cost accounting seeks to identify, quantify and internally allocate all costs associated with an organisation's activities, operations, products and/or services, including environmental, social and other external costs" (ACCA, Account Ability and KPMG [56]). While there are difficulties in measuring the externalities caused by the firm, some companies such as British Petroleum (BP) have implemented a "full cost" system in evaluating projects. BP tracks the impact of a project over its full life cycle including all costs, even those not directly within the firm's control. The costs are classified under four headings: economic, resource use, environmental and social. These costs are then converted into a monetary value (ACCA et al. [56]). Similarly, traditional accounting ignores social benefits produced by a firm while assessing its financial performance. For example, a wildlife park can help to regenerate the population of endangered species of animals by breeding them and releasing the surplus into the wild. If the organisation is assessed on financial grounds, by comparing the revenue in terms of fees collected from visitors with expenses incurred in running the park, then the financial result is understated, unless, some benefit is attributed to the positive externality produced by the park for releasing surplus animals into nature (Deegan [2]).

Firms must engage in CSR thinking beyond the cost $\mathrm{v}$ profit debate because of the potential advantages to adopting CSR. Deegan (2010) argues that CSR practices can affect an organisation's future reputation, brands, ability to attract talented personnel and support from customers and the public. In 2008, the media reported that milk powder imported from China was harmful to human health. This incident had a detrimental effect on the reputation of Chinese milk exporters with more than 25 countries banning dairy imports from China (UNESCAP [57]). As the reputation of the firm exists in the minds of stakeholders ( $\mathrm{Lu}$, Abeysekera, Cortese [58]), firms can influence the perception of stakeholders by engaging in CSR practices and reporting. Thus firms can regain their legitimacy by undertaking CSR. Stakeholders which have an interest in CSR have a positive impression of firms which practise CSR thus enhancing stakeholders' assessment of corporate reputation ( $\mathrm{Lu}$, Abeysekera, Cortese [58]). Toms [59] and Has- 
seldine, et al. [60] find a positive association between CSR reporting and corporate reputation.

CSR can be used to resolve conflicts between the firm and stakeholders. For example, environmentalists may exert pressure to reduce carbon emissions through investments in green technology. Reluctance to meet the demand of stakeholders can endanger the "licence to operate" of the firm. Harjoto and Jo [61] argue that well governed firms will utilize CSR as a mechanism to reduce conflict between managers and stakeholders. Stakeholder's salience is a function of one or combination of the stakeholder's attributes of power, urgency and legitimacy (Mitchell et al., [62]). Textile firms in Bangladesh adopt CSR due to pressure by powerful foreign buyers (Islam and Deegan, [63]). Power depends on the pressure the stakeholder can exert on the firm. Helmig et al. [64]) found that stakeholders indeed exert pressure for firms to implement CSR which leads to better market performance. Notwithstanding the positive effects of CSR, at times, the firm has to agree to stakeholders' requirements even if it has to sacrifice profit.

To sum up, the claim that mandatory CSR will lead to lower profit is valid. However, businesses should go beyond the strict definition of cost and view CSR as an investment which has the potential to reap returns in the future or even a tax paid for using society's services.

\section{Conclusions}

While CSR originates from developed countries, mandatory CSR has been driven by developing countries. The Mauritian CSR levy applies to all companies indistinctively, which means that companies are equally affected by the CSR levy. As such, companies can neither use CSR as a competitive edge nor can they take the public for a "free ride" by reporting CSR without actually practicing it. Perhaps, one innovative way to create a competitive edge through the use of CSR is to go beyond the mandatory threshold. Internal CSR activities are no longer allowed by CSR guidelines, firms willing to carry internal CSR will have to spend more than $2 \%$ of their profit on CSR.

Public interest theory concludes that the CSR levy is appropriate in the Mauritian context due to "market failure". The prevailing local conditions where family businesses dominate the business scene offer no incentives for firms to engage in CSR. Pre-legislation CSR practices provide evidence of a preference for internal CSR which did not benefit society as a whole. Managers did not have to show their managerial talents by engaging in CSR to improve the firm's rating as it happens in developed countries. All elements combined, the Mauritian business environment was not conducive towards voluntary CSR. Thus legislation was warranted in the interests of the community. The CSR levy acts in the public interest to change the focus of CSR activities from internal to external. Rashid and Lodh [65] showed that regulation was necessary in developing countries for firms to practise CSR. 
The Mauritian CSR levy has set a precedent which other countries can follow to institutionalise CSR. For instance, the Indian and Mauritian CSR levy and guidelines have many similarities. While CSR practices originated from developed countries and were quickly adopted by less developed countries (LDC), the trend on mandatory CSR has been set by LDCs.

This paper brings the discussion of voluntary versus mandatory CSR to a new level which takes into account the socio-economic environment in Mauritius. The CSR levy is endorsed for a number of general and specific reasons. This paper discussed three main questions surrounding mandatory CSR: should CSR be mandatory? Does the CSR levy result in a competitive disadvantage? And does the CSR levy reduce profit? It is concluded that the CSR levy in Mauritius does not result in a competitive disadvantage. The uniform rate of $2 \%$ of profits does not differentiate among companies meaning that all companies are affected equally. On the international front, the CSR levy can attract investment as investors from developed countries, and value the practice of CSR. The CSR levy can also facilitate investment by Mauritian companies in countries which attach importance to CSR. The CSR levy will affect profit, the extent will depend on whether the business is involved in CSR activities prior to the CSR levy.

\section{References}

[1] Kristoffersen, I., Gerrans, P. and Clark-Murphy, M. (2005) The Corporate Social Responsibility and the Theory of the Firm. Finance and Economics \& Fimarc Working Paper Series, Edith Cowan University, Perth.

[2] Deegan, C. (2010) Corporate Social Responsibility. CPA Australia Study Guide on Ethics and Governance. CPA Australia, Melbourne.

[3] Bloom, P.N. and Gundlach, G.T. (2001) Handbook of Marketing and Society. Sage, Thousand Oaks. https://doi.org/10.4135/9781452204765

[4] Ioannou, I. and Serafeim, G. (2014) The Consequences of Mandatory Corporate Sustainability Reporting: Evidence from Four Countries. Harvard Business School Research Working Paper, Harvard University, Cambridge. http://doi.org/10.2139/ssrn.1799589

[5] Waagstein, P.R. (2011) The Mandatory Corporate Social Responsibility in Indonesia: Problems and Implications. Journal of Business Ethics, 98, 455-466. https://doi.org/10.1007/s10551-010-0587-x

[6] Meisenhelder, T. (1997) The Developmental State in Mauritius. Journal of Modern African Studies, 35, 279-297. https://doi.org/10.1017/S0022278X97002383

[7] Mahadeo, J.D., Oogarah-Hanuman, V. and Soobaroyen, T. (2011) A Longitudinal Study of Corporate Social Disclosures in a Developing Economy. Journal of Business Ethics, 104, 545-558. https://doi.org/10.1007/s10551-011-0929-3

[8] Soobaroyen, T. and Mahadeo, J.D. (2010) A Study of the Evolution of Community Disclosures in a Developing Country. Proceedings of 6 th Asia-Pacific Interdisciplinary Research on Accounting (APIRA) Conference, Sydney, 22-43.

[9] Pineda Escobar, M.A. (2010) CSR and Public Private Partnerships: The Case of Corporate Social Responsibility in Mauritius. PhD. Dissertation, University of Maastricht, Maastricht.

[10] Ministry of Finance (2007) Budget Speech 2007-2008. 
http://www.gov.mu/portal/site/MOFSite

[11] Godfrey, J., Hodgson, A., Tarca, A., Hamilton, J. and Holmes, S. (2010) Accounting Theory. Wiley \& Sons, Milton.

[12] Deegan, C. (2013) Financial Accounting Theory. 4th Edition, McGraw-Hill Education, Sydney.

[13] Omran, M. and El-Galfy, A. (2014) Theoretical Perspectives on Corporate Disclosure: A Critical Evaluation and Literature Survey. Asian Review of Accounting, 22, 257-286. https://doi.org/10.1108/ARA-01-2014-0013

[14] Gaffikin, M. (2008) Accounting Theory: Research, Regulation and Accounting Practice. Pearson Education, Sydney.

[15] Soobaroyen, T. and Mahadeo, J.D. (2008) Selective Compliance with the Corporate Governance Code in Mauritius: Is Legitimacy Theory at Work? Research in Accounting in Emerging Economies, 8, 239-272. https://doi.org/10.1016/S1479-3563(08)08009-2

[16] Manos, R. and Ah-Hen, C. (2003) Evidence on the Determinants of Capital Structure of Non-Financial Corporates in Mauritius. Journal of African Business, 4, 129154. https://doi.org/10.1300/J156v04n02_07

[17] MohdGhazali, N.A. (2007) Ownership Structure and Corporate Social Responsibility Disclosure: Some Malaysian Evidence. Corporate Governance: The International Journal of Business in Society, 7, 251-266.

https://doi.org/10.1108/14720700710756535

[18] Ntim, C.G. and Soobaroyen, T. (2013) Corporate Governance and Performance in Socially Responsible Corporations: New Empirical Insights from a Neo-Institutional Framework. Corporate Governance: An International Review, 21, 468-494. https://doi.org/10.1111/corg.12026

[19] Al-Bassam, W.M., Ntim, C.G., Opong, K.K. and Downs, Y. (2015) Corporate Boards and Ownership Structure as Antecedents of Corporate Governance Disclosure in Saudi Arabian Publicly Listed Corporations. Business \& Society, 1, 1-43.

[20] National Committee on Corporate Governance (2004) Report and Code on Corporate Governance for Mauritius. Ministry of Finance and Economic Development, Port-Louis.

[21] Lokman, N., Mula, J.M. and Cotter, J. (2014) Importance of Corporate Governance Quality and Voluntary Disclosures of Corporate Governance Information in Listed Malaysian Family Controlled Businesses. International Journal of Sustainable Development \& World Policy, 3, 1-24.

[22] Khan, A., Muttakin, M.B. and Siddiqui, J. (2013) Corporate Governance and Corporate Social Responsibility Disclosures: Evidence from an Emerging Economy. Journal of Business Ethics, 114, 207-223. https://doi.org/10.1007/s10551-012-1336-0

[23] Chau, G.K. and Gray, S.J. (2002) Ownership Structure and Corporate Voluntary Disclosure in Hong Kong and Singapore. The International Journal of Accounting, 37, 247-265. https://doi.org/10.1016/S0020-7063(02)00153-X

[24] Haniffa, R.M. and Cooke, T.E. (2002) Culture, Corporate Governance and Disclosure in Malaysian Corporations. Abacus, 38, 317-349. https://doi.org/10.1111/1467-6281.00112

[25] Ho, S.S. and Wong, K.S. (2001) A Study of the Relationship between Corporate Governance Structures and the Extent of Voluntary Disclosure. Journal of International Accounting, Auditing and Taxation, 10, 139-156. https://doi.org/10.1016/S1061-9518(01)00041-6 
[26] Ghazali, N.A.M. and Weetman, P. (2006) Perpetuating Traditional Influences: Voluntary Disclosure in Malaysia Following the Economic Crisis. Journal of International Accounting, Auditing and Taxation, 15, 226-248. https://doi.org/10.1016/j.intaccaudtax.2006.08.001

[27] Najid, N.A. and Rahman, R.A. (2011) Government Ownership and Performance of Malaysian Government-Linked Companies. International Research Journal of Finance and Economics, 61, 42-56.

[28] Haji, A. and Mohd Ghazali, N. (2013) The Quality and Determinants of Voluntary Disclosures in Annual Reports of Shari'ah Compliant Companies in Malaysia. $\mathrm{Hu}$ manomics, 29, 24-42. https://doi.org/10.1108/08288661311299303

[29] Mauritius Employers Federation (MEF) (2007) MEF Feedback. No. 4, Port Louis.

[30] Japhet, K., Tawiah, V.K. and Benjamin, M. (2015) Debate on Mandatory Corporate Social Responsibility. http://papers.ssrn.com/sol3/papers.cfm?abstract_id=2592880

[31] Mauritius Employers Federation (MEF) (2011) Survey Report on the Practical Implementation of CSR under the New Legislation. Mauritius Employers Federation, Port-Louis.

[32] Blin, M. and Ouattara, B. (2009) Foreign Direct Investment and Economic Growth in Mauritius: Evidence from Bounds Test Cointegration. International Economics, $117,47-61$.

[33] Seetanah, B. (2009) Is Foreign Direct Investment Growth Conducive? New Evidences from Sub-Saharan African Countries, 1980-2005. Applied Econometrics and International Development, 9, 185-201.

[34] Li, X. and Liu, X. (2005) Foreign Direct Investment and Economic Growth: An Increasingly Endogenous Relationship. World Development, 33, 393-407. https://doi.org/10.1016/j.worlddev.2004.11.001

[35] Wahid, A.N. and Seetanah, B. (2009) Determinants of Foreign Direct Investments (FDI): Lessons from the African Economies. The Journal of Applied Business and Economics, 9, 70-84.

[36] Turner, R.J. (2004) Corporate Social Responsibility: Should Disclosure of Social Considerations Be Mandatory? PhD Thesis, Monash University, Melbourne.

[37] Cormier, D., Ledoux, M.J. and Magnan, M. (2011) The Informational Contribution of Social and Environmental Disclosures for Investors. Management Decision, 49, 1276-1304. https://doi.org/10.1108/00251741111163124

[38] O’Rourke, D. (2004) Opportunities and Obstacles for Corporate Social Responsibility Reporting in Developing Countries. http://nature.berkeley.edu/orourke/PDF/CSR-Reporting.pdf

[39] Dhooge, L.J. (2004) Beyond Voluntarism: Social Disclosure and France's Nouvelles Regulations Economiques. Arizona Journal of International and Comparative Law, 21, 441-491.

[40] Deva, S. (2004) Acting Extraterritorial to Tame Multinational Corporations for Human Rights Violations: Who Should "Bell the Cat"? Melbourne Journal of International Law, 5, 37-65.

[41] Porter, M.E. and Kramer, M.R. (2006) Strategy and Society: The Link between Corporate Social Responsibility and Competitive Advantage. Harvard Business Review, 84, 78-92.

[42] McWilliams, A. and Siegel, D. (2001) Corporate Social Responsibility: A Theory of the Firm Perspective. Academy of Management Review, 26, 117-127.

[43] Husted, B.W. and Salazar, J. (2006) Taking Friedman Seriously: Maximizing Profits 
and Social Performance. Journal of Management Studies, 43, 75-91. https://doi.org/10.1111/j.1467-6486.2006.00583.x

[44] Jain, T. and Jamali, D. (2015) Looking inside the Black Box: The Effect of Corporate Governance on Corporate Social Responsibility. Corporate Governance: An International Review, 23, 472-488.

[45] Albinger, H.S. and Freeman, S.J. (2000) Corporate Social Performance and Attractiveness as an Employer to Different Job Seeking Populations. Journal of Business Ethics, 28, 243-253. https://doi.org/10.1023/A:1006289817941

[46] Peterson, D.K. (2004) Benefits of Participation in Corporate Volunteer Programs: Employees Perceptions. Personnel Review, 33, 615-627. https://doi.org/10.1108/00483480410561510

[47] Stites, J.P. and Michael, J.H. (2011) Organizational Commitment in Manufacturing Employees: Relationships with Corporate Social Performance. Business \& Society, 50, 50-70. https://doi.org/10.1177/0007650310394311

[48] Carmeli, A., Gilat, G. and Waldman, D.A. (2007) The Role of Perceived Organizational Performance in Organizational Identification, Adjustment and Job Performance. Journal of Management Studies, 44, 972-992. https://doi.org/10.1111/j.1467-6486.2007.00691.x

[49] Sethi, P. (2005) Investing in Socially Responsible Companies Is a Must for Public Pension Funds-Because There Is No Better Alternative. Journal of Business Ethics, 56, 99-129. https://doi.org/10.1007/s10551-004-5455-0

[50] Barnea, A. and Rubin, A. (2010) Corporate Social Responsibility as a Conflict between Shareholders. Journal of Business Ethics, 97, 71-86. https://doi.org/10.1007/s10551-010-0496-Z

[51] Jo, H. and Harjoto, M.A. (2011) Corporate Governance and Firm Value: The Impact of Corporate Social Responsibility. Journal of Business Ethics, 103, 351-383. https://doi.org/10.1007/s10551-011-0869-y

[52] Orlitzky, M., Schmidt, F.L. and Rynes, S.L. (2003) Corporate Social and Financial Performance: A Meta-Analysis. Organization Studies, 24, 403-441. https://doi.org/10.1177/0170840603024003910

[53] Purushothaman, M., Tower, G., Hancock, G. and Taplin, R. (2000) Determinants of Corporate Social Reporting Practices of Listed Singapore Companies. Pacific Accounting Review, 12, 101-133.

[54] Griffin, J.J. and Mahon, J.F. (1997) The Corporate Social Performance and Corporate Financial Performance Debate. Business and Society, 36, 5-31. https://doi.org/10.1177/000765039703600102

[55] Usman, A.B. and Amran, N.A.B. (2015) Corporate Social Responsibility Practice and Corporate Financial Performance: Evidence from Nigerian Companies. Social Responsibility Journal, 11, 749-763. https://doi.org/10.1108/SRJ-04-2014-0050

[56] ACCA, Account Ability \& KPMG (2009) Accounting Sustainability Briefing Paper 5. Association of Chartered Certified Accountants, Glasgow.

[57] United Nations Economic and Social Commission for Asia and the Pacific (UNES CAP) (2010) Creating Business and Social Value: The Asian Way to Integrate CSR into Business Strategies. Studies in Trade and Investment 68, United Nations, New York.

[58] Lu, Y., Abeysekera, I. and Cortese, C. (2015) Corporate Social Responsibility Reporting Quality, Board Characteristics and Corporate Social Reputation: Evidence from China. Pacific Accounting Review, 27, 95-118. 
https://doi.org/10.1108/PAR-10-2012-0053

[59] Toms, J.S. (2002) Firm Resources, Quality Signals and the Determinants of Corporate Environmental Reputation: Some UK Evidence. British Accounting Review, 34, 257-282. https://doi.org/10.1006/bare.2002.0211

[60] Hasseldine, J., Salama, A.I. and Toms, J.S. (2005) Quantity versus Quality: The Impact of Environmental Disclosures on the Reputations of UK Plcs. British Accounting Review, 37, 231-248. https://doi.org/10.1016/j.bar.2004.10.003

[61] Harjoto, M.A. and Jo, H. (2011) Corporate Governance and CSR Nexus. Journal of Business Ethics, 100, 45-46. https://doi.org/10.1007/s10551-011-0772-6

[62] Mitchell, R.K., Agle, B.R. and Wood, D.J. (1997) Toward a Theory of Stakeholder Identification and Salience: Defining the Principle of Who and What Really Counts. Academy of Management Review, 22, 853-886.

[63] Islam, M.A. and Deegan, C. (2008) Motivations for an Organisation within a Developing Country to Report Social Responsibility Information: Evidence from Bangladesh. Accounting, Auditing and Accountability Journal, 21, 850-874. https://doi.org/10.1108/09513570810893272

[64] Helmig, B., Spraul, K. and Ingenhoff, D. (2016) Under Positive Pressure How Stakeholder Pressure Affects Corporate Social Responsibility Implementation. Business \& Society, 55, 151-187. https://doi.org/10.1177/0007650313477841

[65] Rashid, A. and Lodh, S.C. (2008) The Influence of Ownership Structures and Board Practices on Corporate Social Disclosures in Bangladesh. Research in Accounting in Emerging Economies, 8, 211-237. https://doi.org/10.1016/S1479-3563(08)08008-0 